\title{
Integration Processes with Participation of the Large Companies
}

\author{
Valentina Pavlovna Shelomentseva ${ }^{1}$, Lyudmila Mikhailovna Davidenko ${ }^{2, *}$ \\ ${ }^{1}$ Department of Economics and management, Innovative University of Eurasia, 140003, Pavlodar city, Republic of Kazakhstan \\ ${ }^{2}$ Department of accounting and finance, Innovative University of Eurasia, 140003, Pavlodar city, Republic of Kazakhstan \\ *Corresponding Author: davidenkolm@rambler.ru
}

Copyright (C) 2014 Horizon Research Publishing All rights reserved.

\begin{abstract}
This paper summarizes the best practices in corporate management, law and integration management based on merger and acquisition transactions. The analysis of modern integration policy and investment policy of the Republic of Kazakhstan from the perspective of expanding economic ties with Europe has been carried out. A retrospective and contemporary assessment of the integration processes in the most attractive sectors of Kazakhstani economy has been given. The recommendations on the formation of process-oriented concept of the company's growth based on merger and acquisition transactions have been developed.
\end{abstract}

Keywords Economic Integration, Mergers, Acquisitions, Europe, Russia, Kazakhstan

\section{Introduction}

This template is formatted according to advice of some experts. The innovative activity of Kazakhstan enterprises depends on the dynamics of economic systems of macro-level development: the state of global financial system and global oil, gas, ferrous and non-ferrous metals market. This may be due to the fact that the main part of the market participants of the Republic of Kazakhstan scientific-research complex and business-structures belong to the raw material industry sectors which provide the gross domestic product (GDP) growth.

Industrial and innovative development of national economy in many respects is defined by enterprise climate which is formed and is subject to continuous influences of the various factors, having impact on business activity.

Integration of Kazakhstan into the world economy is connected with the purpose of occurrence into thirty of the most developed countries of the world, full participation in the twenty of large national economies of G-20 "Group of Twenty Finance Ministers and Central Bank Governors".

In the detailed analysis of the region enterprise climate from set of factors it is accepted to allocate the subgroups united by the terms "investment climate", "tax climate", "innovative climate" and "business climate".

The analysis of statistics for the period from 2008 till 2012 shows us that the level of the GDP growth and the volume of industrial production and investments is lower than it was before the world crises of 2007 (Table 1), [1].

Table 1. The dynamics of indicators of macroeconomic development of the Republic of Kazakhstan (in \% to the previous year)

\begin{tabular}{|c|c|c|c|c|c|}
\hline Indicator & 2008 & 2009 & 2010 & 2011 & 2012 \\
\hline $\begin{array}{c}\text { Gross domestic } \\
\text { product (GDP) }\end{array}$ & 103,3 & 101,2 & 107,3 & 107,5 & 105,0 \\
\hline $\begin{array}{c}\text { Industrial } \\
\text { production }\end{array}$ & 102 & 103 & 110 & 103,5 & 100,5 \\
\hline $\begin{array}{c}\text { Capital } \\
\text { investments }\end{array}$ & 105 & 103 & 97 & 102,4 & 104 \\
\hline
\end{tabular}

Kazakhstan's economy is referred to a type of economy of developing countries, and the dynamics to the openness and security for private investment is clearly observed. This is supported by the international community.

Despite the efforts there is an acute problem to overcome the negative trends, such as [2]:

- weak economic diversification with the predominance of extractive industries;

- lack of high-tech equipment and manufacturing facilities with high added value;

- lack of transparency and predictability of business environment;

- lack of foreign direct investment.

To overcome the structural deformation and enhance the innovative activity is possible using special financial economic instruments, including the integration at the level of companies with mergers and acquisitions (merger and acquisition transactions, M\&A), as well as forms of international cooperation without direct equity (Non-Equity Modes of International Production) [3].

Therefore, the aim of this study is to reveal the essence of global integration processes (including merger and acquisition transactions, M\&A) and adaptation of international experience to the Kazakhstan's economy to enhance its transparency. 


\section{Structural and Logical Scheme of Scientific Research of processes of M\&A}

The aim of scientific research: to reveal the essence of global integration processes (including merger and acquisition transactions, M\&A) and adaptation of international experience to the Kazakhstan's economy to enhance its transparency.

Tasks of scientific research:

- to generalize the advanced experience in corporate management, law and integration of management;

- to characterize the merger and acquisitions as part of a successful business development strategy;

- to develop a process-oriented model of based on mergers and acquisitions.

- Methods and techniques of scientific research:

- analysis of statistical information;

- comparative and systematic analysis in the study of the mechanisms of implementation and M\&A processes;

- diagnostics and forecasting.

Stages of scientific research: explanation of the essence of corporate strategy aimed at the development of business integration: financial and economic basis; legal basis; assessment of advanced experience in corporate management using $M \& A$ transactions.

\section{Essence of Corporate Strategy Aimed at the Development of Business Integration}

\subsection{Financial and Economic Foundations of Corporate Management of Integration Processes}

An important role in the development and implementation of an effective business strategy by integrating is carried out by the scientific and research works of famous scientists and consulting firms.

Scientific developments touch both historical analysis and forecasts of companies' development. So Richard Brealey, Stewart Myers [4] in their work "Principles of corporate finance" reveals the essence of mergers and acquisitions as an economic category. Along with this work, a professional interest is attracted by the statistics of M\&A market of the United States of America, tracked over the 90-s.

A special place in this study is given to the observation of trends and methods of cost estimating, the payment, sellers and buyers' motivation. Frank C. Evans, David M. Bishop [5] interpret the term "strategic synergism", appreciate objective and subjective factors of forecast of merger or acquisition synergy.

The scientists of the Commonwealth of Independent States are studying the European, American experience and adapt it to their own economic, legal conditions. The researcher Ignatishin J.V. [6] gave a description of the sources, forms and methods of financing of M\&A transactions in Russia.

Gomcjan S.V. [7] in his monograph presented findings based on a comparative legal analysis of the acquisition of joint stock companies in Russia and the European Union.

For the scientists, concerned with the assessment of sustainable development and investment attraction, the works of Novikov A.V. [8], Endovitsky D.A., Soboleva V.E. [9], are of great interest. These scholars have focused on the study of the investment characteristics of the M\&A processes.

The definition of the M\&A process within the legal legislation is in the Law of the Republic of Kazakhstan "On joint stock companies" [10]. The merger of companies is recognized as the emergence of a new company through the transfer of the entire property, rights and obligations under the merger agreement and in accordance with the transfer acts of two or more companies to cease their activity. At the same time the charter capital of a company formed by the merger of companies, is the sum of the equity of the reorganized companies. It historically developed that any corporation that wishes to increase its value through integration, bases on growth strategy, including M\&A transactions. The aim to increase the value is the starting point for choosing strategic alternatives, as M\&A transactions have meaning only if they provide the value growth of the company [11].

According to international practice regulated by the International Financial Reporting Standard (IFRS) 3 "Business Combination", a business combination is defined as a transaction or event in the result of which an acquirer obtains control over one or more types of businesses [12].

Business is defined as an interrelated set of activities and assets managed in order to provide investors or other owners with income. As the basic mechanisms of business combination reflected in the standards there are four types presented in (Figure 1).

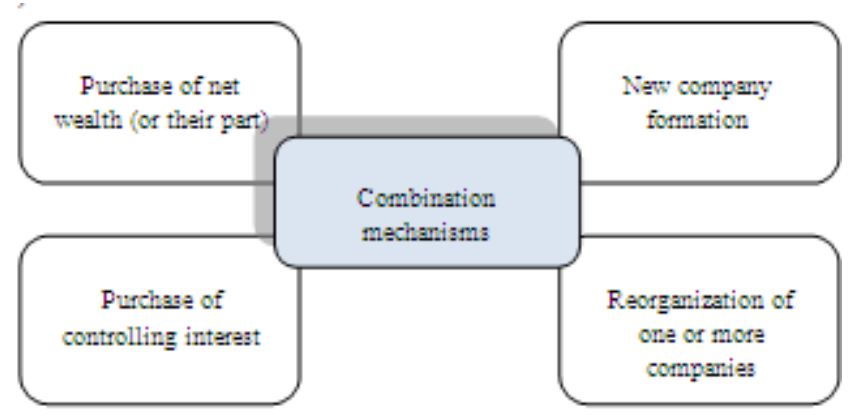

Figure 1. usiness Combination Mechanisms According to (IFRS) 3 Business Combinations

Recent economic studies show that now multinational companies make extensive use of models of development based on contracting industrial and agricultural manufacturing, transfer of services to outsourcing (outsourcing), franchise and licensing. 
However, the integration processes at the level of companies also involve direct participation in the capital of companies - partners, i.e. M\&A transactions. Such transactions can be carried out both among small firms, and at the level of transnational corporations.

Despite the fact that the growth of companies through M\&A is more expensive than licensing, franchising, outsourcing, it is able to improve the economic, social responsibility of the newly formed company or the company - buyer to the employees of the acquired company. In the case of integration of companies without equity participation there is a high risk of refusal of the service company, under contractor's agreement with the main corporation, or the probability of termination of the contract before the expiration if there is a company - analogue.

\subsection{The Legal Bases o Integration Processes Regulation}

Turning to the Kazakhstan's experience of regulation of operations on the integration of companies one can focus on important issues that relate to economic concentration and the participation of foreign companies. In 2009 the Republic of Kazakhstan introduced a new law "On Competition" [13]. The law "On Competition" was prepared in the period of the beginning of the economic recession, at the time of the burst of mergers and acquisitions. The processes of economic concentration led to fundamental changes in the fuel and energy complex, chemical industry, telecommunications and banking environment of the Republic of Kazakhstan.

The law of economic concentration, subject to preliminary agreement with the antitrust authority, admits:

- merger or acquisition of market entities;

- acquiring by a person $25 \%$ or more percent of shares of market entity;

- getting basic fixed production assets and (or) intangible assets of another entity of the market into the ownership;

- the acquisition by the market entity the rights enabling to determine the business activity in another market entity;

- participation of the same individuals in the administrative organs of two or more market entities provided the determination of business activity.

In connection with the expansion of the international borders the urgency of legal regulation of business combination involving foreign partners is growing. The share of foreign participation in authorized capital is limited in the Republic of Kazakhstan: air transport - 49\%; mass media - 20\%; telecommunications and the main lines of communication - $49 \%$; financial sector: pension funds $-25 \%$ [13].

International practice shows that the observance of legitimacy of transactions on business combinations is the basis for their future financial well-being.

\subsection{Studies of Advanced Experience i Corporate Management o Integration Processes}

Merges and merger of the companies throughout all the history had wavy character. It is possible to note five most expressed waves in development of these processes:

- wave of M\&A of 1887-1904;

- merges of the companies in 1916-1929;

- wave of conglomerate merges in the 60-70th years of our century;

- wave of M\&A in the eighties;

- merges of the 90th years;

- merges of the 2000th years.

Merges to formation of conglomerates are now least popular. Their number includes also such well-known companies, as "General Electric", the American conglomerates "Textron Inc" and "United Technologies Corp", British "Hanson", Dutch "Philips Electronics", Italian "Montedison", etc. But all these conglomerates reoriented the activity on those segments in which they are in the lead. Now they get the companies in key spheres of business and sell all non-key assets.

A striking example of a corporate culture based on M\&A transactions, is a corporation "Cisco" - hi-tech industry representative. The corporation "Cisco" has 25- year history, for the period of 1993-2009 the company acquired 129 companies and $85 \%$ of the employees of the acquired companies kept jobs in acquired structures [14]. "Cisco", being the product of venture investment, controls the venture capital of more than two billion dollars. As the exchange of innovative experience one can focus on the following positions of integration policy "Cisco".

Characteristic Features of Corporate Development Strategy of the Corporation "Cisco".

Compliance with corporate strategy: to make the world more comfortable for work, study and rest.

Aims of corporate development strategy:

- Using the market transition condition and holding the leading position of "Cisco"in the sector.

- Ensuring the optimal level of investment, acquisitions, technology and partnership relations.

Structure of corporate development department:

- subgroup of business development;

- technology subgroup.

Principles of functioning the corporate development department: performance of various functional responsibilities and close cooperation in the interest of maximizing growth of the strategic potential of each market initiative.

The quality criteria for a positive decision on the question of new acquisition:

- the target company must have a solid business and share strategic views on business and technology "Cisco";

- the target company must have a solid business and share strategic views on business and technology "Cisco".

The quantitative criteria of a positive decision on the question of new acquisition:

- the prospect of getting the revenue from a newly 
acquired company of the amount of $\$ 1$ billion a year;

- the resource-saving policy, preference to the companies operating in close proximity to areas of "Cisco" functioning.

The composition of the investment portfolio:

- direct investment: China Communications Services (\$ 100 million), VMware (U.S. \$ 150 million), Nimbus Communications (\$20 million), Alibaba (17,5 million), and others;

- venture capital funds: Softbank Asia Infrastructure Funds I, II and III, Bodhi (China and India), CoreOptics (Italy, India, USA), 3TS-Cisco Growth Fund III (Central and Eastern Europe), CXC (China), Almaz Capital Partners (Russia), etc.

The "Cisco" partnership programs are of great interest in IT industry. In late 2009 for the first time in CIS in Kazakhstan, the IP project - new generation network based on optical networking solutions of "Cisco" has been implemented. When implementing the project "Cisco Systems" actively cooperates with "Kazakhtelecom".

The corporation "Cisco" uses financial mechanisms to maintain profitability of partners and companies entered the corporation. For example, the employees of the company developed a financial program "Cisco Capital", which allows purchasing the equipment "Cisco" on credit on reasonable terms. The users of the program are companies with high reputation, good credit history, expanding business with "Cisco".

One of the most important factors of success of the transaction on merge or merger of the companies is compatibility of management style of two uniting companies. There is a mass of examples when after transaction end the buyer appoints one of the managers to head the bought business. Management style of this head goes to a section with management style of the main team of other company. It causes the mass of the conflicts and the subsequent discontent and dismissal as managers, and the staff of the acquired company, including key. Efficiency of activity of the acquired business falls. Thus, it is necessary to understand in advance distinction level between management styles of two companies. Complexity of adaptation of styles and their mutual integration arises at each association. In our opinion, it is necessary to define and develop absolutely new management style which will suit both companies and to prevent bulk of the conflicts.

Harmonizing business relations can serve as a basis for conducting mutually beneficial transactions in the near future connected not only with the realization of assets but also the integration of corporate business - structures of new generation with participation of Kazakhstan's firms.

\subsection{Characteristics of the Integration Processes i te Most Attractive Sectors o Kazakhstan Economy}

Economic concentration may serve as an indicator of $\mathrm{M} \&$ A market. The analysis of the current situation of competition development in Kazakhstan shows that some sectors of economy are over concentrated. In particular, such sectors as railway, communication, air transportation, oil and gas, fuel and energy, pharmaceutics, as well as the spheres with state participation. The "Program on the Development of Competition in the Republic of Kazakhstan for 2010-2014" [15] reports about the presence of threats from the monopolies' side in the country's economy, even if the companies operating in these markets now are competitive.

The growth of the size of a functioning enterprise is equated to the strong side of business, economies of scale, market leadership. The borders of growth are regulated by law. According to the analytical data of the Agency of the Republic of Kazakhstan on Competition Protection (Antimonopoly Agency) it is possible to trace the dynamics of numbers of mergers and acquisitions among the market entities for the period of 2008-2012 (Table 2).

Table 2. information about the state of economic concentration in Kazakhstan for the period from 2008 till 2012

\begin{tabular}{cccccc}
\hline $\begin{array}{c}\text { The index of } \\
\text { economic } \\
\text { concentration }\end{array}$ & 2008 & 2009 & 2010 & 2011 & 2012 \\
\hline $\begin{array}{c}\text { The number of } \\
\text { petitions about } \\
\text { granting of consent } \\
\text { for economic } \\
\text { concentration }\end{array}$ & 387 & 308 & 313 & 286 & 395 \\
$\begin{array}{c}\text { The number of issued } \\
\text { permittances }\end{array}$ & 224 & 134 & 150 & 120 & 138 \\
$\begin{array}{c}\text { The number of } \\
\text { subjects in the State } \\
\text { Register of market } \\
\text { entities which are } \\
\text { holding the dominant } \\
\text { or monopoly position }\end{array}$ & 969 & 945 & 612 & 600 & 617 \\
\hline
\end{tabular}

Note: compiled by the authors according to the source [16].

As compared with 2007 in 2008, the number of permissions for economic concentration has increased by $7 \%$. According to data for 2009 the Antimonopoly Agency received 308 petitions for consent to economic concentration [16]. The data presented show that, despite the expansion of customs borders, the total number of application for merger in 2011 is lower as compared with 2010. On the basis of official data one can state that the number of mergers over the past three years is below pre-crisis indicators, then we see that there is a tendency to decrease the level of concentration. Moreover, transactions concluded with foreign firms are supported which increases the international status of the state before the potential investors.

The confirmation of this serves the example of the transaction at the end of 2010, made in the banking sector according to the resolution of the Board of the Antimonopoly Agency of November 28, 2010 № 295-OD “ On granting the consent to economic concentration of the company" Punjab National Bank" (PNB), New Delhi, India. According to the Kazakhstan Stock Exchange KASE that is now JSC "DanaBank" renamed to JSC "Subsidiary bank "Punjab National Bank "JSC" SB "PNB" - Kazakhstan" is a 
subsidiary of Punjab National Bank. The Indian Bank acquired 3500000 common voting shares of JSC "Danabank" which is $63.64 \%$ of all issued shares [17]. According to analysts of "BATT" Investment Company (the owner of approximately $10 \%$ of shares of JSC "Danabank"), for several years, the bank plans to take place among the top ten banks in Kazakhstan, and with further expansion in the CIS Kazakhstan bank will be the basic structure.

In 2011 permission for the merger by acquiring shares in the authorized capital and acquiring assets, the following market participants received: "Mineral Resourcez BVBA", "Soldesa Indonesia BV", "Pepsi-Cola (Bermuda) Limited", "Laybridge limited", "Gemini Oil \& Gas Investments BV", "Medeu Holdings BV", LLC "Eurasia leasing", LLC "SBS Trade", LLC "Technocentre Ltd", LLC "KazPetroDrilling", LLC Tivit Energy Kazakhstan", LLC "Allur Tech", LLC "CNPC International", LLC "SDB Group", "Cisco Systems". The sectoral belonging of these firms is different, but all participants have a chance to enter new stage of development, entering the capital of other market entities, or acquiring new types of assets. From this list you can single out one company that has chosen a strategy of integration and business diversification through mergers and acquisitions as a basic way of development.

According to reports "The People's IPO" (2013), Beginning since 2012 Kazakhstan launched the program "The People's IPO" in accordance with the draft of Government of the Government Of Kazakhstan [18]. The Commission has carried out the selection of companies whose shares will be placed at the Kazakhstan Stock Exchange KASE step-by-step in over several years. The companies of the first echelon will enter the market first: JSC "KazTransOil" (oil transportation, export and import of petroleum and petroleum products); JSC Kazakhstan Electricity Grid Operating Company "KEGOC" (electrical power engineering).

The second echelon of companies approximately includes: JSC "KazTransGas" (gas transportation systems and main pipelines); JSC NMSC Kazmortransflot (sea freight); JSC Samruk-Energo - Holding on Management of power assets in Kazakhstan (heat power engineering and electrical power engineering).

The third echelon: JSC "NC" Kazakhstan temir zholy" (passenger, transit, cargo transportation); JSC "Kaztemirtrans" (freight rail); National Company KazMunayGas JSC (exploration, production, processing and transportation of oil and gas); NAC Kazatomprom JSC (import-export of uranium, rare metals, nuclear fuel for nuclear power plants, special purpose equipment, technologies and dual-use materials).

Considering Kazakhstan's M\&A market across sectors, analysts note that the most universal is still oil and gas sector. The other sectors of the economy, which large M\&A transactions were concluded from 2009 to 2013 became the banking, mining and metallurgical industries.

\subsection{Recommendations for the Development of Processes Oriented of Based on Mergers and Acquisitions}

The concept is based on a process approach to managing the integration of companies in M\&A. The concept is informational - analytical framework consisting of the description of the M\&A transactions of domestic companies over the past three years.

At the initial stage it is necessary to identify the quantitative and qualitative parameters of growth, the time horizon, which will match the plans for business expansion and development of the company in whole.

The condition of Kazakhstan business environment is reflected in the reports of Interfax-Kazakhstan News Agency, information-analytical service of centre Business Resource Central Asia (BRCA), "BCC Invest" JSC, "Halyk Finance" JSC, Financial portal PROFINANCE, "Aibn Asset Management" JSC, “Asia Capital” JSC, "Greenwich Capital Management" JSC, Group of companies Resmi, "Sayat Zholshy \& Partners"a law firm , "GRATA" law firm and others.

\section{The stage of $M \& A$ implementation}

The most significant and responsible stage is connected with estimating the cost of a target company, defining synergetic effect of transaction of M\&A. Approaches to business estimation are multidirectional since many-sided nature of the transaction "purchases - sales" must be taken into account. According to group of experts in the field of an estimation of investment appeal led by Novikov A.B. [8], to increase the probability of a reliable estimate, experts appraisers traditionally use the set of three directions: the profitable approach (capitalization-of-earnings method and discounting method); the market approach (method of public company - analogue and method of transactions M\&A); the approach on assets (adjusted book value method and liquidation value method).

Experience shows that exactly at an evaluation stage there may be miscalculations which can turn out to be serious problems and even a negative outcome of the whole operation on merger of firms. The reasons of such errors lie in the following: poor quality of the information received at the previous stages of "due diligence", unduly overestimated evaluation of the synergetic effect; change of the external factors little depending on participants of transaction M\&A; in particular, consequences of financial crisis when strategy of the companies' growth by means of mergers and acquisitions have undergone serious adjustments. The analysis of materials on the perfect and successfully conducted transactions shows, that synergies can be reached in such functional areas as personnel, marketing, engineering business - processes, optimization of resource provision, qualitative and quantitative parameters of production (services) produced by newly established or expanded in the course of M\&A firm.

Review of M\&A of Republic Kazakhstan corporations, such as Eurasian Natural Resources Corporation PLC 
(ENRC), KAZAKHMYS, allows drawing a conclusion on necessity of using the following criteria when estimating the expediency of the future transaction: growth of a correlation of market capitalization of the estimated company ("P") and proceeds from sales of production, services (symbolic representation "N"); indicator growth of earnings per share "EPS", or net income per share, as correlation of the total net profit of the united companies and total quantity of shares of the united companies.

\section{Integration stage}

At this stage social aspects and human values since merger of the companies demands an individual approach to workers of the firms which are subject to merger or acquisition are important. The success of integration will be defined by continuity of corporate traditions, observance of the rights and duties of the people occupied in given firms.

In Using the concept will allow firms to create a real process model strategy of growth through mergers and acquisitions. The process of implementation of M\&A is expedient to split into five main stages inherent in the various stages of mergers and acquisitions (Figure 2).

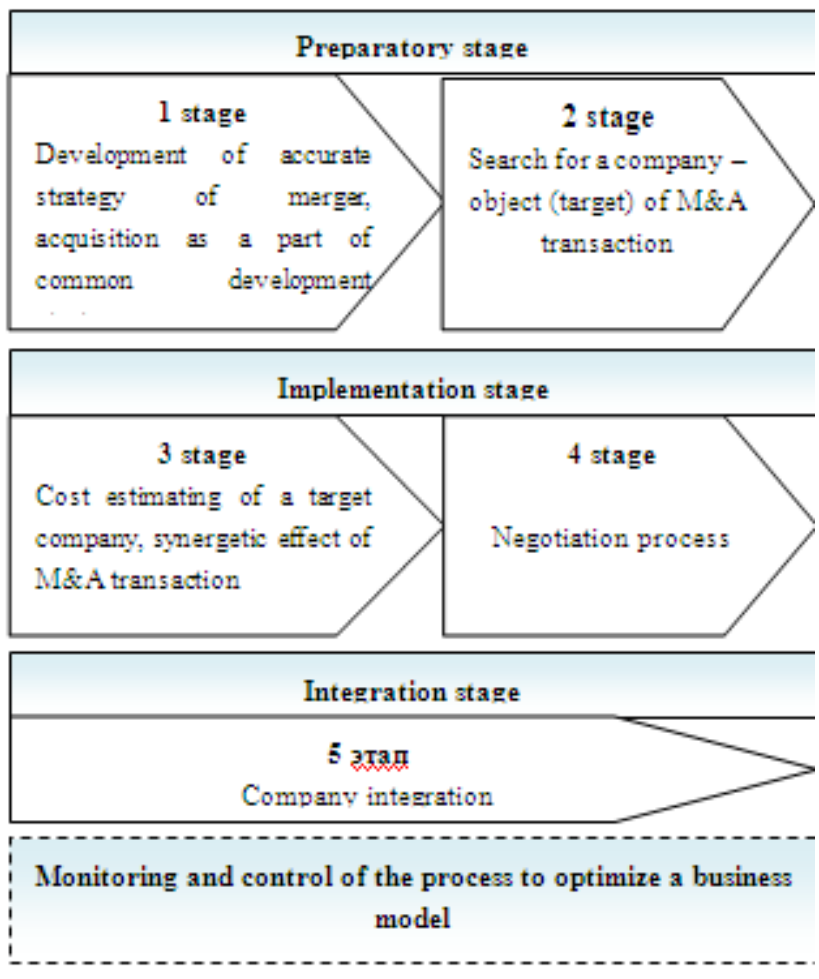

Figure 2. Process of Implementation of Strategy of M\&A

In the conclusion, we can emphasize that the process approach to organization of mergers and acquisitions allows minimizing all types of risks that accompany M\&A transactions.

\section{Conclusion}

Global changes in the world economy is a complex process that takes place under the influence of a set of socio-economic and political factors. In this case the main factor of economic growth of a single state may be called the investment attractiveness of sectors of its economy, i.e. quantitative and qualitative indicators of inflow and outflow of capital that contribute to the strengthening of its internal and external socio-economic policy.

Measures to increase the investment attractiveness are the formation of an effective integration policy development, implementation of specific government programs, overcoming of structural deformation, support of efficient and competitive enterprises, transformation of old ties, identification of specific investment and innovation priorities, continuous monitoring of the country's economy.

The most important indicator of investment climate in any country in the world is M\&A transactions. Their nature, qualitative and quantitative parameters, sectoral belonging carry an objective assessment of the state functioning from side of the strategic partners. Meanwhile the key indicator is the dynamics of foreign direct investment. Direct foreign investments are a means by which transnational corporations and groups realize the industrial migration from some countries and regions to the other ones, make mergers and acquisitions (M\&A) of required assets.

The analysis of international practice shows that the transactions at M\&A market are mainly international and carried out to enter a new country. Therefore, it is not surprising that the development of the market is held with a significant participation of foreign capital. Undisputed leaders in the level and dynamics of integration processes are the countries of the European Union. Among the CIS countries Russia and Kazakhstan play a significant role in the transformation of bilateral economic relations. The crisis has brought its changes in all economic phenomena, including the processes of companies' combination: reduction in the number and value of transactions in 2007-2008, and a gradual increase in 2009-2011. Kazakhstan managed to reach a positive economic growth, which in 2012 made up $105 \%$.

For the Kazakhstan companies integration into world economic system is an incentive to the further economic growth and increase of competitiveness of the state economy, and also possibility of effective use of transit potential.

The third year in a row in world mining and metallurgical industry is observed reduction of number of transactions of merge and absorption. According to analysts, accurate signals of steady restoration of the prices of raw materials are necessary for M\&A restoration in this branch.

While the offer prevails over demand, and sellers are compelled to reduce an assessment of the assets. Thus the buyers limited in means, don't hurry to use reduction of prices. Generally assets are got today by the investors having the state support, and also financial investors, such as investment funds and the direct investment funds, having opportunity long to hold similar assets, counting on market restoration.

In the first half of the year of the current year in world mining and metallurgical industry 350 transactions were 
made by total cost of 78,6 billion dollars, the number of transactions was reduced by $30 \%$ in comparison with the similar period of last year. The cumulative cost of transactions grew by $41 \%$, but generally thanks to only two transactions: to merge of the Glencore International and Xstrata companies for the sum of 37,8 billion dollars and to acquisition by the Inmet Mining Corporation company First Quantum Minerals company for 5,1 billion dollars.

As a result of $80 \%$ of cost of all transactions it was necessary on 10 of the largest. In the first half of last year of 12 largest transactions provided only $30 \%$ of cumulative cost of all transactions [19].

In 2013 year the American ConocoPhillips reported about completion of process of sale of $8,4 \%$ of shares in Kashagan's Kazakhstan oil field. Shares were redeemed by the national Kazakhstan company "KazMunaiGas" (KMG) which has used the privilege. It was originally planned that the buyer will act as the Indian ONGC Videsh Limited. The amount of transaction made 5 billion dollars. Later "KazMunaiGas" reported that reached the agreement on sale of $8,33 \%$ of shares in a field of the Chinese CNPC for 5 billion dollars. Kashagan - a large-scale oil and gas deposit in Kazakhstan, located in the north of the Caspian Sea. Geological stocks are estimated at 4,8 billion $t$ of oil. The general oil stocks make 38 billion barrels or 6 billion t, of them taken - about 10 billion barrels [19].

The analysis of prospects of the Kazakhstan and world markets of merges and absorption in the conditions of world financial crisis, allows to allocate the following tendencies: merger of the problem companies and enterprises; increase in number of transactions of merges and absorption in the global technological companies; active participation of the state in transactions of merges and absorption as participant and the regulator in replacement of the private capital in venture transactions.

Creation of joint enterprises possibly in hi-tech spheres of the third industrial revolution, such as [20]:

- pure power;

- robotics;

- nanotechnologies;

- space industry;

- genetic engineering, etc.

According to forecasts of experts in the period of 2014-2016 years the investment of oil savings of National fund of the Republic of Kazakhstan in national economy will be carried out. The guaranteed transfer from National fund has consisted 1380 billion Kazakh tenge (over 9 billion dollars of United States) annually. In 2014 year it is supposed to attract a target transfer from National fund on the sum of 150 billion Kazakh tenge (about 1 billion dollars of United States) [21].

Target use is the specific infrastructure projects; the result of their realization has to become the increase in transit transportations and advance of the Kazakhstan export at the world markets. The project of the budget provided continuation of implementation of the Map of industrialization, the Road map of business, the Road map of employment, Programs of develoment of regions and monotowns, programs "Affordable housing" and "Agro business programs 2020" [22].

In the conclusion it is important to note that globalization of world economy is accompanied by strengthening of the international and regional economic integration, in this connection, interdependence between the states, regions grows. The companies, irrespective of the sizes, forms of ownership and branch accessory, are primary link of these relations. Therefore the condition of enterprise climate plays a paramount role in productivity of integration process at macroeconomic and microeconomic levels.

\section{Acknowledgements}

We are very grateful to experts for the appropriate and constructive suggestions to improve this research.

\section{REFERENCES}

[1] A.A Smailov.Kazakhstan in figures: The statistical data on social-economic status of the Republic of Kazakhstan /in English/, Agency of the Republic of Kazakhstan on Statistics, Astana, http://www.eng.stat.kz/, 2013.

[2] N. Nazarbaev. SCO: ten years of history // "Russian newspaper", June, 3 2011, "Official site of President of the Republic of Kazakhstan". Available at: http://www.akorda.kz/ru/speeches/articles/shos, 2011.

[3] A. Dahmen. Strategische Einflussfaktoren von M\&A-Transaktionen. Doctoral (PhD) thesis. West-Hungarian University, Doctoral School Istvan Szechenyi, Sopron, 2010.

[4] Brealey, Richard A., Stewart C. Myers and Franklin Allen, Principles of Corporate Finance, McGraw-Hill/Irwin, pp: 1028, 2008.

[5] Frank C. Evans, David M. Bishop. Valuation for M\&A: Building Value in Private Companies, p. 101-111, 2004.

[6] J.V. Ignatishin. Mergers and acquisitions: Strategy, tactics, finance - Saint-Petersburg, Peter Print, p. 29-31, 2005.

[7] S.V. Gomcjan. The rules of acquisition of joint-stock companies: comparative and legal analysis: monography. Moscow, Volters Cluver, p. 64-97, 2010.

[8] A.V. Novikov. Evaluation of investment cost of a company, Institute of economics and organization of industrial production SB RAS, NSUEM. Novosibirsk, p. 352, 2009.

[9] D.A. Endovitsky, V.E. Soboleva. Financial analysis of mergers and acquisitions of the companies. Moscow, Publishing house "KnoRus", p. 188-227.446 p., 2010.

[10] Law of the Republic of Kazakhstan of 13 May 2003 N 415 On joint-stock company, Newspaper "Kazakhstan's truth" of 16 May 2003, No. 141-142.

[11] Reinhard Steinocker. Akquisitionscontrolling: Strategical 
planning of Firmenubernahmen: Concept, transaction, integration. Berlin, p 17-21, 1993.

[12] The international standard of the financial reporting (IFRS) 3 Business Combinations, http: //static.bdo.uk.com/imported/2010/3/IFRS_3Business_Comb inations.pdf., 2008.

[13] Law of the Republic of Kazakhstan "On competition" of 25 December 2008 No 112-IV, 2008. http://www.azk.gov.kz/rus/ml/npbazza/cgtrnm/.

[14] H. Romanski "We paid special attention to the acquisition of companies which could bring 1,0 billion dollars a year"// Journal “Merger and Acquisition” No 3 (73), p. 17-23, 2009.

[15] "Program on the development of competition in the Republic of Kazakhstan for 2010-2014": Agency of the Republic of Kazakhstan on competition protection, Astana, 2010. http://www.azk.gov.kz/data/filedat/default/77777.doc.

[16] Statistics and reports "About petition to economic concentration" Agency of the Republic of Kazakhstan on economic competition (Antimonopoly agency), 2013. http://www.azk.gov.kz/eng/.

[17] Working Paper "JSC "Danabank" (Kazakhstan) reported about its renaming into JSC "Subsidiary bank "Punjab National Bank". July 2011. Kazakhstan Stock Exchange Joint-Stock Company (KASE). http://www.kase.kz/news/sho w/1141128.

[18] Programm "People's IPO”. Date Views 01.01.2013 http://www.halyk-ipo.kz/en/.

[19] Information Agency MAonline.ru http://www.maonline.ru/

[20] Eurasian Emerging Markets Forum (EEMF) "Eurasia in the XXI century: leadership through updating" materials, September, 2013 // http://kazakh-tv.kz/ru/view/news_kazakh stan/page_28166_otkrytie-evraziiskogo-foruma-razvivayush chikhsya-rynkov.

[21] Presentation of the budgetary bills, September, 2013 / Official site of Parliament of the Republic of Kazakhstan / http://www.parlam.kz/en.

[22] "Fund Damu" Programs // Official site Entrepreneurship Development Fund JSC "DAMU” // http://www.damu.kz/68. 